Please do not remove this page

RMIT

UNIVERSITY

\title{
P2Y12 receptor: platelet thrombus formation and medical interventions
}

Moheimani, Fatemeh; Jackson, Denise

https://researchrepository.rmit.edu.au/esploro/outputs/9921858525301341/filesAndLinks?institution=61RMIT_INST\&index=null

Moheimani, F., \& Jackson, D. (2012). P2Y12 receptor: platelet thrombus formation and medical interventions. International Journal of Hematology, 96(5), 572-587.

https://doi.org/10.1007/s12185-012-1188-5

Document Version: Accepted Manuscript

Published Version: https://doi.org/10.1007/s12185-012-1188-5

Repository homepage: https://researchrepository.rmit.edu.au

(c) The Japanese Society of Hematology 2012

Downloaded On 2023/04/26 23:06:59 +1000

Please do not remove this page 
Thank you for downloading this document from the RMIT Research Repository.

The RMIT Research Repository is an open access database showcasing the research outputs of RMIT University researchers.

RMIT Research Repository: http://researchbank.rmit.edu.au/

\section{Citation:}

Moheimani, F and Jackson, D 2012, 'P2Y12 receptor: platelet thrombus formation and medical interventions', International Journal of Hematology, vol. 96, no. 5, pp. 572-587.

See this record in the RMIT Research Repository at:

https://researchbank.rmit.edu.au/view/rmit:17864

Version: Accepted Manuscript

Copyright Statement: (C) The Japanese Society of Hematology 2012

Link to Published Version:

The Japanese Society of Hematology 2012 


\section{Title Page}

Title:

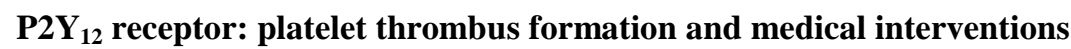

Full author names and affiliations:

Fatemeh Moheimani

Denise E. Jackson

Thrombosis and Vascular Diseases Laboratory, Health Innovations Research Institute, School of Medical Sciences, RMIT University

\section{Type of Manuscript:}

Review article

\section{Running head:}

$\mathrm{P} 2 \mathrm{Y}_{12}$ receptor, thrombosis and intervention

\section{Corresponding author and full contact information:}

Fatemeh Moheimani

Thrombosis and Vascular Diseases Laboratory, Health Innovations Research Institute, School of Medical Sciences, RMIT University, PO Box 71, Bundoora, VIC 3083, Australia

Phone number: + 61399257815

Email address: fatemeh.moheimani@rmit.edu.au 


\begin{abstract}
There are a wide range of receptors and proteins on platelets playing essential roles in thrombus formation. Among them $\mathrm{P}_{2} \mathrm{Y}_{12}$ receptor, a member of the $\mathrm{G}$ protein-coupled receptor family, has attracted lots of attention. Stimulation of $\mathrm{P} 2 \mathrm{Y}_{12}$ receptor by ADP results in activation of various signaling pathways involved in amplification of platelet activation and aggregation. There have been extensive attempts to design an ideal antithrombotic agent to block $\mathrm{P} 2 \mathrm{Y}_{12}$, which has a selective expression, as an intervention for cardiovascular disease. Current inhibitors of $\mathrm{P} 2 \mathrm{Y}_{12}$ receptor include indirect inhibitors or thienopyridines family (ticlopidine, clopidogrel and prasugrel), and direct $\mathrm{P}_{2} \mathrm{Y}_{12}$ inhibitors (ticagrelor, cangrelor and elinogrel). Among them clopidogrel is the most common prescribed $\mathrm{P}_{2} \mathrm{Y}_{12}$ blocker however this product has not met the ideal therapeutic standards. The main limitations of clopidogrel administration include slow onset, prevention of recovery of platelet functions, and interindividual variability. Hence, advanced studies have been carried out to achieve more efficient and safer $\mathrm{P} 2 \mathrm{Y}_{12}$ blockade. In this review we provide a comprehensive, yet brief, report on the overview of $\mathrm{P} 2 \mathrm{Y}_{12}$, its role on platelet thrombus formation and targeting this receptor as an intervention for cardiovascular disease, for the benefit of basic science and clinical researchers.
\end{abstract}

\title{
Key words
}

Platelet . P2Y 12 receptor. Signaling pathways . Indirect inhibitors . Direct inhibitors 
Introduction

Platelets play an essential role in both the normal hemostasis maintenance and the pathological thrombus formation development [1]. For example, within atherosclerotic arteries subject to high shear stress platelets in conjunction with other factors are responsible in vascular occlusion, a crucial mechanism in myocardial infarction and stroke [1]. Platelet thrombi can lead to clinical consequence of cardiovascular or cerebrovascular disease that is associated with $36 \%$ of all deaths in Australia [2].

After vascular injury, platelets translocate and rapidly adhere to exposed subendothelial matrix components including von Willebrand factor (vWF) and collagen through adhesive receptors including GPIb-IXV complex and GPVI-FcR $\gamma$-chain complex, respectively. Platelet membrane GPIb $\alpha$ recognizes the activated conformation of $\mathrm{vWF}$, initiating intracellular signaling events that lead to integrin $\alpha \operatorname{IIb} \beta 3$ activation. In the process of platelet adhesion, signals are also generated that lead to platelet activation. Platelet activation involves activation of integrin $\alpha \mathrm{IIb} \beta 3$ leading to platelet shape change and spreading, formation of stable platelet adhesion, release of granule contents, generation of lipid mediators and accumulation of platelet aggregates to form a thrombus [3]. Activation of platelets is achieved through a variety of cell surface receptors such as Gprotein coupled receptors, integrins and glycoprotein receptors. A positive feedback loop by physiological agonists such as thrombin and collagen is also initiated by secreted products and secondary mediators of platelet activation. These secondary mediators include adenosine diphosphate (ADP: released from platelet granules) and thromboxane $\mathrm{A}_{2}$ (generated within platelets) which activate other platelets and amplify the recruitment of platelets to a growing thrombus. Secreted ADP is important for platelet activation, as patients with defects in dense granule storage or specific ADP receptors have bleeding abnormalities [4].

ADP mechanism of action is through two G-protein coupled receptors, the $\mathrm{G}_{\mathrm{q}}$-coupled $\mathrm{P} 2 \mathrm{Y}_{1}$ receptor and the $\mathrm{G}_{\mathrm{i}}$-coupled $\mathrm{P} 2 \mathrm{Y}_{12}$ receptor. The $\mathrm{P} 2 \mathrm{Y}_{1}$ receptor contributes to ADP-induced platelet shape change while the $\mathrm{P} 2 \mathrm{Y}_{12}$-coupled $\mathrm{G}_{\mathrm{i}}$ signaling is essential for potentiation of dense granule secretion, thromboxane $A_{2}$ generation, irreversible aggregation and stabilization of a platelet thrombus $[5,6]$. Concomitant signaling through both ADP receptors is necessary and sufficient for fibrinogen receptor (integrin $\alpha \operatorname{IIb} \beta 3$ ) activation [5, 6]. Parallel to these events, collagen-induced platelet activation through GPVI and induces integrin $\alpha$ IIb $\beta 3$ activation, resulting in adhesion and aggregation.

The main purpose of this review article is to provide a comprehensive and concise review on $\mathrm{P} 2 \mathrm{Y}_{12}$ receptor on a wide range from its discovery, its role in platelet thrombus formation, deficiency of this receptor and pharmacological inhibition of this receptor with different drugs to overcome cardiovascular disease.

\section{Overview of $\mathrm{P} 2$ receptors}

Nucleotide receptor family known as P2 receptors mediate the actions of extracellular nucleotides to intercellular signaling [7]. Membrane-bound P2-receptors consist of two classes of membrane receptors; P2X ligand-gated cation channels and $\mathrm{G}$ protein-coupled P2Y receptors [1, 8]. Mammalian P2X receptors are classified into 7 distinct subtypes $\left(\mathrm{P} 2 \mathrm{X}_{1}-\mathrm{P} 2 \mathrm{X}_{7}\right)$ that are distributed throughout the body and response to endogenous agonist of adenosine triphosphate (ATP) [9]. P2X receptors are expressed abundantly in the nervous system, underlie fat purinergic synaptic transmission, and play important roles in nervous system and peripheral diseases [9].

To date, 8 subtypes of $\mathrm{P} 2 \mathrm{Y}$ receptor $\left(\mathrm{P} 2 \mathrm{Y}_{1}, \mathrm{P} 2 \mathrm{Y}_{2}, \mathrm{P}_{2} \mathrm{Y}_{4}, \mathrm{P} 2 \mathrm{Y}_{6}, \mathrm{P} 2 \mathrm{Y}_{11}, \mathrm{P} 2 \mathrm{Y}_{12}\right.$ and $\left.\mathrm{P} 2 \mathrm{Y}_{13}, \mathrm{P}_{2} \mathrm{Y}_{14}\right)$ have been cloned and characterized $[1,10,11]$. The jump in sequence of the P2Y numbering is due to the mistake in 
identification of certain receptors which are assumed to belong to this family such as $\mathrm{P}_{2} \mathrm{Y}_{5}$ and $\mathrm{P}_{2} \mathrm{Y}_{7}$ [8] or nonmammalian $\mathrm{P} 2 \mathrm{Y}$ receptors (chicken $\mathrm{p} 2 \mathrm{y} 3$ and Xenopus laevis $\mathrm{p} 2 \mathrm{y} 8$ receptors) [8, 12]. $\mathrm{P} 2 \mathrm{Y}_{9}$ and $\mathrm{P} 2 \mathrm{Y}_{10}$ receptors are not nucleotide receptors, either [8]. P2Y receptors are widespread with a different range of physiological roles [7]. They are distributed through cells and tissues such as platelets ( $\mathrm{P} 2 \mathrm{Y}_{1}$ and $\mathrm{P} 2 \mathrm{Y}_{12}$ ) to epithelia $\left(\mathrm{P}_{2} \mathrm{Y}_{2}\right.$ and $\left.\mathrm{P}_{2} \mathrm{Y}_{4}\right)$, placenta $\left(\mathrm{P}^{2} \mathrm{Y}_{4}\right)$, heart, blood vessels and brain $\left(\mathrm{P}_{2} \mathrm{Y}_{6}\right)$, immunocytes $\left(\mathrm{P} 2 \mathrm{Y}_{11}\right)$ and neural cells $\left(\mathrm{P}_{2} \mathrm{Y}_{1}\right.$ and $\left.\mathrm{P}_{2} \mathrm{Y}_{12}\right)$ [7]. Based on their pharmacological aspects, $\mathrm{P} 2 \mathrm{Y}$ receptors can be subclassified into adenine nucleotide sensitive receptors mainly responding to adenosine diphosphate (ADP) and ATP (P2 $\mathrm{Y}_{1}$, $\mathrm{P}_{2} \mathrm{Y}_{11}, \mathrm{P}_{2} \mathrm{Y}_{12}$ and $\mathrm{P} 2 \mathrm{Y}_{13}$ ), the uracil nucleotide sensitive receptors responding to uridine triphosphate (UTP) or uridine diphosphate (UDP) $\left(\mathrm{P}_{2} \mathrm{Y}_{4}\right.$ and $\mathrm{P}_{2} \mathrm{Y}_{6}$ ), the mixed sensitive receptor $\left(\mathrm{P}_{2} \mathrm{Y}_{2}\right)$, and UDP-glucose sensitive receptor $\left(\mathrm{P}_{2} \mathrm{Y}_{14}\right)$ [10]. Furthermore, according to their functional coupling to specific $\mathrm{G}$ proteins and effector proteins, $\mathrm{P} 2 \mathrm{Y}$ receptors can be subdivided to $\mathrm{G}_{\mathrm{q}}$-coupled subtypes; $\mathrm{P} 2 \mathrm{Y}_{1}, \mathrm{P} 2 \mathrm{Y}_{2}, \mathrm{P} \mathrm{Y}_{4}, \mathrm{P} \mathrm{Y}_{6}$ and $\mathrm{P} 2 \mathrm{Y}_{11}$, and $\mathrm{G}_{\mathrm{i}^{-}}$ coupled subtypes; $\mathrm{P} 2 \mathrm{Y}_{12}, \mathrm{P}_{2} \mathrm{Y}_{13}$ and $\mathrm{P} 2 \mathrm{Y}_{14}[13]$.

Among $\mathrm{P} 2$ receptors only $\mathrm{P} 2 \mathrm{X}_{1}, \mathrm{P}_{2} \mathrm{Y}_{1}$ and $\mathrm{P} 2 \mathrm{Y}_{12}$ are expressed at significant levels in platelets of healthy volunteers, with the $\mathrm{P} 2 \mathrm{Y}_{12}$ is expressed at the highest extent followed by $\mathrm{P} 2 \mathrm{X}_{1}$ and $\mathrm{P} 2 \mathrm{Y}_{1}$, respectively [14]. Two of $\mathrm{P} 2 \mathrm{Y}$ receptors play essential roles in platelet thrombus formation. The $\mathrm{P}_{2} \mathrm{Y}_{1}$ receptor initiates platelet activation in response to ADP and participates in platelet aggregation mediated by collagen [15]. The $\mathrm{P}_{2} \mathrm{Y}_{1}$ receptor is coupled to $\mathrm{G} \alpha \mathrm{q}$ and initiates calcium mobilization from internal stores inducing platelet shape change and weak and transient aggregation mediating by ADP [16-18]. In general, the $\mathrm{P}_{2} \mathrm{Y}_{1}$ receptor mediates weak responses to ADP and is crucial in the early steps of platelet activation mediated by ADP or collagen [1]. Whilst, the $\mathrm{P}_{2} \mathrm{Y}_{12}$ receptor completes and amplifies platelet activation and aggregation [1].

\section{$3 \quad \mathbf{P 2} \mathbf{Y}_{12}$ receptor}

P2 $\mathrm{Y}_{12}$ receptor has been shown to expressed in human, bovine, rat and mouse tissues [7]. The identity of the platelet $\mathrm{P} 2 \mathrm{Y}_{12}$ receptor was characterized in 2001 by using expression cloning [19] and ligand screening methods $[20,21] . \mathrm{P} \mathrm{Y}_{12}$ is highly expressed in human platelets and to a smaller extent in brain [19]. Some of the essential roles of $\mathrm{P} 2 \mathrm{Y}_{12}$ receptor are platelet aggregation in addition to inhibition of neural cells [7]. $\mathrm{P} 2 \mathrm{Y}_{12}$ receptor is activated by ADP (a natural agonist stored in platelet dense granules) and very potently by ADP analogue 2methylthio-ADP (2-MeSADP) [7]. ATP and its triphosphate analogues (e.g. 2MeSATP and 2ClATP) are P2Y 12 antagonists [22, 23]. Other nucleotide antagonists include $N^{6}$-(2-methylthioethyl)-2-(3,3,3-trifluoropropylthio)$\beta, \gamma$-dichloromethylene-ATP (cangrelor; AR-C69931MX), and the nucleoside analogue AZD6140 [7]. In addition, active metabolites of the thienopyridine compounds, clopidogrel, ticlopidine and prasugrel block this receptor [7]. These $\mathrm{P}_{2} \mathrm{Y}_{12}$ antagonists have been administered in pharmacotherapy to inhibit platelet aggregation [7].

\subsection{Biochemistry of $\mathrm{P}_{2} \mathrm{Y}_{12}$ receptor}

The $\mathrm{P}_{2} \mathrm{Y}_{12}$ receptor structure contains the specific features of G-protein-coupled receptors including 7 hydrophobic transmembrane (TM) regions connected by 3 extracellular loops (EL) and 3 intracellular loops (Fig. 1) [7]. The human $P 2 Y_{12}$ receptor consists of 342 amino acid residues [1]. The human $P 2 Y_{12}$ amino acid sequence contains 10 cysteine residues. There are four cysteine residues at extracellular domains at position 17 , 97, 175 and 270 which are proposed to form 2 disulfide bridges between N-terminal domain and EL3, and 
between EL1 and EL2 [7, 24]. Ding et al., however showed that there is no essential disulfide bridge between cysteines 17 and 270 [25]. In addition, there are five cysteine residues at position 194, 208, 248, 292, and 302 located in the TM domains, and one intracellular cysteine residue is present at position 315 [24]. The importance of cysteine residues in the function of $\mathrm{P} 2 \mathrm{Y}_{12}$ has been proposed by the ability of thiol reagents, e.g. clopidogrel, to inhibit ADP responses in platelets [19]. Although $N$-linked glycosylation of the $\mathrm{P} 2 \mathrm{Y}_{12}$ receptor plays an essential role in signal transduction, it is not crucial for ligand binding or cell surface expression [26].

\subsection{Overview of $\mathrm{P}^{2} \mathrm{Y}_{12}$ signaling pathways in platelets}

Guanine nucleotide-binding regulatory proteins, also known as $\mathrm{G}$ proteins, mediate the interaction between cell surface receptors and intracellular enzyme generation second messenger molecules during platelet activation [27]. The $G$ proteins are multimers, e.g. $G_{i}, G_{s}, G_{o}, G_{t}, G_{p}, G_{z}, G_{q}$ [27-29], consist of three distinct subunits including $\alpha, \beta$ and $\gamma$ existing in more than one form [27]. For example, two G proteins distributed in virtually all cells include, $\mathrm{G}_{\mathrm{s} \alpha}$; the $\alpha$ subunit of the $\mathrm{G}$ protein that stimulate cyclic adenosine monophosphate (cAMP) formation by adenyl cyclase, and $\mathrm{G}_{\mathrm{i} \alpha}$; the $\alpha$ subunit of the $\mathrm{G}$ protein that inhibits adenyl cyclase [30].

Human platelets expressed $G_{q}$, four members of the $G_{i}$ family of $G$ proteins including $G_{i 1}, G_{i 2}, G_{i 3}$ and $\mathrm{G}_{\mathrm{z}}[27-29,31], \mathrm{G}_{\mathrm{s}}, \mathrm{G}_{12}, \mathrm{G}_{13}$ and $\mathrm{G}_{16}[28,32,33]$. It has been shown that $\mathrm{G}_{\mathrm{q}}$ pathway plays a vital role in platelet aggregation [34]. Two of the most highly expressed $G_{i}$ proteins on platelets are $G_{z}$ that couples to the $\alpha_{2 A}$ adrenergic receptor for epinephrine [35], and $\mathrm{G}_{\mathrm{i} 2}$ that is the target of the ADP receptor P2 $\mathrm{Y}_{12}$ [36].

The $\mathrm{P} 2 \mathrm{Y}_{12}$ receptor couples to $\alpha_{\mathrm{i} 2}$ subunit of $\mathrm{G}$ protein (Fig. 2) [19, 36, 37]. Stimulation of the heterotrimeric $G$ protein, e.g. by ADP, results in dissociation of $G \alpha$ and G $\beta \gamma$ subunits which activate various signaling pathways [6]. The $\mathrm{G} \alpha_{\mathrm{i} 2}$ inhibits production of adenyl cyclase which results in reduction in cytosolic cAMP concentrations [36, 38, 39]. This decrease in cAMP reduces the activation of cAMP-dependent protein kinase (PKA) responsible for phosphorylation of the vasodilator-stimulated phosphoprotein (VASP) [1]. VASP phosphorylation plays an essential role in fibrinogen receptor activation in response to ADP and platelet aggregation [40]. VASP is an actin regulatory protein that inhibits the integrin $\alpha \operatorname{IIb} \beta 3$ activation [41, 42]. Therefore, the levels of VASP phosphorylation/dephosphorylation can indicate $\mathrm{P} 2 \mathrm{Y}_{12}$ inhibition/activation as well as a selective assay for clopidogrel effects on patients, e.g. patient resistance to clopidogrel [43, 44].

On the other hand, it has been shown that stimulation of $\mathrm{P}_{2} \mathrm{Y}_{12}$ by ADP, through G $\beta \gamma$ subunits, stimulates phosphatidyl inositol-3 kinase (PI-3K) activity (Fig. 2), resulting in late accumulation of phosphatidylinositol 3,4-bisphosphate $\left(\operatorname{PtdIns}(3,4) \mathrm{P}_{2}\right)$ induced by PAR1-activated peptide and rapid and transient accumulation of phosphatidylinositol $(3,4,5)$-trisphosphate $\left(\operatorname{Ptd} \operatorname{Ins}(3,4,5) \mathrm{P}_{3}\right)$, with essential roles in sustaining platelet aggregation [45-47]. Various isoforms of PI3K are expressed in platelets. Two major isoforms of PI3K present in platelets include PI3K $\beta$, a member of the class Ia isoforms which consists of catalytic subunit of $\mathrm{p} 110 \alpha$ and $\mathrm{p} 110 \beta$ regulated by tyrosine kinases, and PI3K $\gamma$ belonging to the class $\mathrm{Ib}$ isoform which consists of catalytic subunit of p110 $\gamma$ activated by G-protein coupled receptors [48-51]. Continual signaling through PI3K $\beta$ and $\mathrm{PI} 3 \mathrm{~K} \gamma$ via $\mathrm{P} 2 \mathrm{Y}_{12}$ receptors stimulated by $\mathrm{ADP}$ is indicated to be required for stabilizing thrombus growth resulting in maintenance of $\alpha \operatorname{IIb} \beta 3$ activity and fibrinogen binding [48].

It has been also elucidated that P2 $\mathrm{Y}_{12}$ activates GTPase Rap1b via PI-3K dependent pathway with essential roles in platelet activation (Fig. 2) [31, 47, 52, 53]. Rap1b is the most abundant Ras GTPase in platelets [52]. Rap1b is located at membrane of resting platelets and associates with actin-based cytoskeleton after platelet 
stimulation [52]. Rap1b cycles from inactive form (GDP-bound) to an active form (GTP-bound) regulated by guanine nucleotide-exchange factors, guanine nucleotide dissociation inhibitors and GTPase-activating proteins $[54,55]$. Multiple pathways for Rap1b activation has reported in human platelets including $\mathrm{Ca}^{2+}$, cAMP, protein kinase $\mathrm{C}$ and tyrosine kinases after using different agonists [52, 55]. In response to ADP however it is speculated that PI3K $\beta$ plays an essential role in a signaling pathway between $\beta \gamma$ dimers released upon stimulation of the Gicoupled receptors and activation of Rap $1 \mathrm{~b}$ whereas PI3K $\gamma$ isoform was demonstrated to not be involved in this process $[47,56]$. Rap1b is rapidly activated after stimulation with ADP, in a Gi-dependent pathway through the action of the $\mathrm{PI} 3 \mathrm{~K}$ product $\mathrm{PtdIns}(3,4,5) \mathrm{P}_{3}$ which is a rapid and transient product but not the $\mathrm{PtIns}(3,4) \mathrm{P}_{2}$ which forms mainly as a result of integrin $\alpha \mathrm{IIb} \beta 3$-mediated platelet aggregation [47]. This supports the role of Rap $1 b$ activation in the initial process of platelet activation resulting in activation of integrin $\alpha \operatorname{IIb} \beta 3$ and platelet aggregation [47].

In addition, activation of PI-3K results in dual phosphorylation (threonine 308 and serine 473) hence activation of Akt (Fig. 2) by phosphatidylinositol dependent kinases (PDKs), which is an important signaling intermediate in agonist-induced platelet activation [57, 58]. Akt (or protein kinase B: PKB or RAC) is a family of intracellular serine/threonine protein kinases, expressed in various cells, activated by different agonists, e.g. platelet derived growth factor, insulin and thrombin, and has multifunctional roles, e.g. prevention of apoptosis, regulation of glycogenesis and controlling glucose uptake [57, 59]. Human platelets express Akt1 $(\mathrm{PKB} \alpha)$ and Akt2 (PKB $\beta)$ [57, 59]. PI3K products including PtIns $(3,4) \mathrm{P}_{2}$ and $\operatorname{PtdIns}(3,4,5) \mathrm{P}_{3}$ initiate phosphorylation of Akt $[57,60]$ by PDK 1 at threonine 308 and possibly PKD 2 [57, 60] or autophosphorylation [61] or integrin-linked kinase [62] at serine 473. Membrane attachment of Akt and dual phosphorylation are essential for activation of Akt [57, 59]. Akt activation in a PI3K dependent manner after thromboxane $A_{2}$ or thrombin stimulation promotes ADP release from platelets dense granules that stimulates $\mathrm{P}_{2} \mathrm{Y}_{12}$ receptor signaling pathways resulting in enhancement of integrin $\alpha \mathrm{IIb} \beta 3$-mediated platelet aggregates and stabilization [63]. Therefore ADP amplifies Akt activity [63]. Also, it has been demonstrated that Akt2 plays a more essential role in this process in mice as compared with Akt1 [63].

Furthermore, the $\beta \gamma$ dimers can activate the G-protein-gated inwardly rectifying potassium channels (GIRKs) via binding to their cytosolic regions mediating activation of Src tyrosine kinases downstream [64, 65]. Both GIRK channels and Src family of tyrosine kinases after stimulation of P2Y 12 may play a role in ADPinduced cytosolic phospholipase $\mathrm{A}_{2}\left(\mathrm{CPLA}_{2}\right)$ phosphorylation (serine 505) and thromboxane $\mathrm{A}_{2}$ generation hence platelet aggregation [64] (Fig. 2). Src family tyrosine kinases belong to cellular signal transduces that can be activated by different extracellular signals to modulate various cellular functions, e.g. proliferation, survival, adhesion and migration [66]. Platelets contain high amount of proto-oncogene product pp60 $60^{\mathrm{c}-s \mathrm{rc}}$ which is suggested to be associated with platelet cytoskeletal proteins and important in platelet aggregation [67, 68]. It has been proposed that Src family tyrosine kinases stimulate the extent of $\alpha \operatorname{IIb} \beta 3$ activation but they are not essential in this process [69]. It is also speculated that both $\mathrm{P} 2 \mathrm{Y}_{1}$ and $\mathrm{P} 2 \mathrm{Y}_{12}$ can activate $\mathrm{Src}[69,70]$.

Also, extracellular-signal-regulated kinase (ERK) is suggested to be downstream of Src family kinases [71] (Fig. 2). ERK is a subgroup of mitogen-activated protein kinases (MAPKs) family of serine-threonine kinase activated by various extracellular stimuli, such as growth factors and hormones [72]. It has been shown that platelets expressed two forms of ERK, ERK1 (p44 $\left.{ }^{\mathrm{mapk}}\right)$ that remains intact after thrombin-mediated platelet activation whereas ERK2 (p42 $\left.{ }^{\text {mapk }}\right)$ becomes phosphorylated [73]. Similarly, ADP stimulation results in 
phosphorylation of ERK2, predominantly [74]. It has been proposed that activation of $\mathrm{cPLA}_{2}$ is a downstream link between ERK and integrin activation [72, 73] (Fig. 2).

Signaling through both the $\mathrm{P} 2 \mathrm{Y}_{12}$ and $\mathrm{P} 2 \mathrm{Y}_{1}$ receptor has been shown to be important for ADP-induced ERK2 phosphorylation in platelets therefore generation of thromboxane $\mathrm{A}_{2}[71,74]$ (Fig. 2). cPLA is a Ca $^{2+}$ dependent lipase and cleave arachidonic acid containing phospholipids at their $s n-2$ position releasing arachidonic acid that is a precursor to lipoxins, thromboxanes, leukotrines, prostaglandin eicosanoid and platelet activating factor [75]. Various agonists regulate $\mathrm{CPLA}_{2}$, including hormones, neurotransmitters and antigens, and MAPK and protein kinase C may activate cPLA2 [75]. Phosphorylation of $\mathrm{cPLA}_{2}$ at serine 505 has been proposed to be downstream of ERK-2 stimulation and essential for hormonally mediated release of arachidonic acid from membrane-bound phospholipids hence generation of thromboxane $A_{2}[74,76]$.

We have attempted to summarize signaling pathways responsible for $\mathrm{P}_{2} \mathrm{Y}_{12}$ activation in platelets in this review. However there are various paradoxical reports on the $\mathrm{P} 2 \mathrm{Y}_{12}$ signaling pathways due to complexity of this network. Hence the precise signaling pathway has yet remained to be elucidated.

\section{The $\mathrm{P}_{2} \mathrm{Y}_{12}$ receptor deficiency}

Congenital $\mathrm{P}_{2} \mathrm{Y}_{12}$ deficiency is an autosomal recessive disorder [77, 78]. $\mathrm{P} 2 \mathrm{Y}_{12}$ deficiency is associated with deletions of the nucleotide in the open-reading frame, and frameshift mutation leading to protein premature truncation (e.g., $\mathrm{P} 2 \mathrm{Y}_{12}$ haploinsufficiency and a 378delC mutation in patients remaining allele [79]), or with substitution of a nucleotide in the transduction initiation codon (e.g. ATG to ACGG [80]) [77]. Congenital dysfunctions of $\mathrm{P} 2 \mathrm{Y}_{12}$ are associated with molecular malfunctions of the sixth trans-membrane domain (a G- to -A transition in one allele hence altering the codon for Arg-256 in the sixth trans-membrane domain to Gln) or the nearby third extracellular loop of the receptor ( $\mathrm{C}-$ to $-\mathrm{T}$ transition in the other allele hence altering the codon for Arg-265 in the third extracellular loop to Trp) [4]. The integrity of this region of the protein is crucial for normal receptor function [4]. A heterogeneous mutation, predicting a lysine to glutamate (Lys174Glu) substitution was reported to be associated with the impaired ligand binding to the $\mathrm{P}_{2} \mathrm{Y}_{12}$ receptor in patient with mild type 1 von Willebrand disease [77, 81]. Hence this mutation is suggested to play an essential role in disruption of the ADP-binding site of the $\mathrm{P}_{2} \mathrm{Y}_{12}$ receptor [77, 81].

Platelets with a moderate $\mathrm{P} 2 \mathrm{Y}_{12}$ deficiency show similar characteristics to the primary secretion defect (PSD). The PSD which is characterized by abnormal secretion but normal granule stores, thromboxane $\mathrm{A}_{2}$ production and ADP-initiating aggregation, is the most common platelet congenital defect [78]. The P2 $\mathrm{Y}_{12}$ deficiency results in dysfunctional platelets and bleeding diathesis, characterized by mucocutaneous bleeding and excessive post-surgical and posttraumatic blood loss [78, 82, 83]. The first patient with selective defect of platelet response to ADP was described in 1992 by Cattaneo et al. [84]. This patient (white origin, aged 49) had lifelong history of excessive bleeding (especially mucosal: nose bleeds), easy bruising, prolonged bleeding time, and abnormality in platelet aggregation the same as PSD, including reversible platelet aggregation in response to weak agonists and decreased aggregation induced by low concentrations of collagen or thrombin with the most defect at aggregation responses to ADP [78, 84]. This platelet aggregation is similar to platelet profiles after administration of thienopyridines (e.g. clopidogrel) to humans [78, 85]. More cases with a similar profile have been reported $[77,82,83]$. These cases also emphasize the pivotal role of platelet ADP receptors for normal platelet secretion and function [83]. 
P2 $\mathrm{Y}_{12}$ deficiency can be diagnosed by lack of ADP (even at high concentration: $\geq 10 \mu \mathrm{M}$ ) mediated irreversible platelet aggregation while inducing normal shape change [77]. The diagnosis can be confirmed by assessment the degree of adenyl cyclase inhibition by ADP via measuring cAMP levels in platelets or the phosphorylation of VASP after exposure of platelets to $\mathrm{PGE}_{1}[77,86]$.

The intravenous administration of the vasopressin analogue desmopressin has produced shortening of the prolonged bleeding times and may prevent excessive bleeding complication after surgical procedures observed in these patients [78].

\section{5}

\section{P2Y 12 inhibitors}

$\mathrm{P} 2 \mathrm{Y}_{12}$ receptor has a very limited and selective distribution on tissues [8, 19]. In addition, this receptor plays a crucial role in the thrombus formation and stabilization [1]. Therefore, $\mathrm{P} 2 \mathrm{Y}_{12}$ receptor is a very good candidate for antiplatelet drugs [19]. Ideal antithrombotic agent is characterized by its predictable pharmacodynamics profile (avoid monitoring), rapid onset, rapid offset (and/or available antidote), compatible with adjunctive medicine, potent efficacy, low risk, low cost and easy administration [87].

Current inhibitors of $\mathrm{P} 2 \mathrm{Y}_{12}$ receptor are categorized into indirect acting irreversible inhibitors (thienopyridines: ticlopidine, clopidogrel and prasugrel), and direct acting reversible $\mathrm{P} 2 \mathrm{Y}_{12}$ inhibitors (ticagrelor, cangrelor and elinogrel) [87].

\subsection{Thienopyridines family}

Thienopyridines are the first family of $\mathrm{P}_{2} \mathrm{Y}_{12}$ inhibitor [87]. Thienopyridines are prodrug required to be metabolized by hepatic cytochrome P-450 (CYP) to form active metabolite [87]. The active metabolite then covalently (via formation a disulfide bond with cysteine residues) and irreversibly binds to the $\mathrm{P} 2 \mathrm{Y}_{12}$ receptor hence inhibiting the $\mathrm{P} 2 \mathrm{Y}_{12}$ receptor [87].

\subsubsection{Ticlopidine}

Ticlopidine is the first generation of thienopyridines [87]. This prodrug is administered orally twice a day [88] and reaches the maximum platelet inhibitory effect after 3 days of treatment [89]. Various clinical trials reveal that combination of ticlopidine with aspirin enhances platelet inhibitory effect and reduces cardiovascular events especially in patients undergoing placement of coronary artery stents [89-92]. This synergic effect is contributed to platelet inhibitory effect through blocking two different pathways including $\mathrm{P}_{2} \mathrm{Y}_{12}$ and cyclooxygenase (COX)-1 [93]. Ticlopidine administration however causes serious side effects including neutropenia, aplastic anaemia, thrombotic thrombocytopenic purpura, and gastrointestinal effect which are a drawback of using this medicine [94].

\subsubsection{Clopidogrel}

Clopidogrel (Plavix/Iscover [94]), the most commonly prescribed drugs worldwide [95], belongs to the second generation of thienopyridines, with fewer side effects and replaced ticlopidine [87, 96]. Anti-aggregating property of clopidogrel is also several times greater than ticlopidine [97]. Furthermore, various clinical trials, such as percutaneous coronary intervention - Clopidogrel in Unstable angina to prevent Recurrent Events (PCICURE), Clopidogrel for Reduction of Events During Observation (CREDO) and PCI- Clopidogrel as Adjunctive 
Therapy (CLARITY) trials or Clopidogrel versus Aspirin in Patients at Risk of Ischemic Events (CAPRIE) trial, have revealed cost-effective of pre-treatment and long-term treatment in percutaneous coronary intervention or prevention atherothrombotic events with clopidogrel [98-100].

Clopidogrel is also an inactive prodrug which becomes active after intravenous or oral administration with no trace of circulating activity in the plasma of treated animals or humans [97]. An intravenous formulation of clopidogrel (PM103) has been developed as an alternative dosage form to oral clopidogrel for administration in the acute care setting [101]. Absorbed clopidogrel undergoes two metabolic pathways: about $85-90 \%$ of the absorbed drug is hydrolyzed by esterases that generate inactive metabolite whereas only $10-15 \%$ is metabolized by CYP isoforms in the liver to form an active metabolite [102, 103]. The short lived active metabolite then binds irreversibly to the cysteine 17 and cysteine 270 in the extracellular domains of $\mathrm{P} 2 \mathrm{Y}_{12}$ receptor on platelets hence clopidogrel effects last for the whole platelet lifespan ( $7-10$ days) [25, 102]. The antiplatelet effects of clopidogrel are time and dose dependent with the approximately $50-60 \%$ inhibition of platelet aggregation [104]. The approved doses of clopidogrel are a $300 \mathrm{mg}$ loading dose and a $75 \mathrm{mg}$ of maintenance dose $[94,105,106]$. In addition, combination of clopidogrel with aspirin resulting in concurrent inhibition of $\mathrm{ADP}$ and thromboxane $\mathrm{A}_{2}$ pathways of platelets hence causes additive/synergic antithrombotic effects in patients undergoing coronary stenting [94]. A loading dose of $600 \mathrm{mg}$ of clopidogrel also reveals more potency and efficacy in clinical practice, e.g. percutaneous coronary intervention [107-109].

Although clopidogrel is the most popular antiplatelet drug with high efficacy, it does not have the main criteria of the ideal antithrombotic agent [87]. The antiplatelet effect of clopidogrel is delayed since this prodrug needs to undergo hepatic metabolism to generate an active metabolite. Maintenance daily dose of clopidogrel (75 $\mathrm{mg}$ ) with no preload reaches the steady state levels of platelet aggregation within $4-7$ days. This delayed onset of action of clopidogrel was overcome by administration of loading doses $(300-600 \mathrm{mg})$ that reach the steady state level by $4-24$ h [104, 110, 111].

Another disadvantage of administration of clopidogrel is the substantial variability between individual in platelet inhibition, e.g. a reduced efficacy of clopidogrel in some patients [110]. The high interindividual variability of the response and incidence of drug resistance can affect clinical outcomes extensively since poor responders may receive inadequate protection from major adverse cardiac effects, e.g. patients undergoing percutaneous coronary intervention $[111,112]$. Several studies showed approximately $8-44 \%$ of prevalence of clopidogrel non-responsiveness/resistance [111-116]. This variable response may be due to differences between individual in the conversion of prodrug to active metabolite because of variable CYP3A4 metabolic activity [113]. Several studies also showed that common loss of function polymorphisms of CYP2C19 and CYP2C9 are concomitant with reduced exposure to the active metabolite of clopidogrel [117, 118]. Different extent of absorption of prodrug or clearance of the active metabolite may also play a role in clopidogrel resistance [110]. Clopidogrel efflux via P-glycoprotein ATP-dependent pump encoded by the ABCB1 gene (also known as MDR1) [95]. Patients with genetic variants in ABCB1 (ABCB1 3435 TT homozygotes) are more likely to experience adverse cardiovascular outcomes after clopidogrel treatment [95]. Furthermore, $\mathrm{P} 2 \mathrm{Y}_{12}$ receptor variability, such as elevated level of receptors, enhanced level of ADP or upregulation of other platelet activation pathways may cause interindividual variation is response to clopidogrel [110].

Further limitation of clopidogrel is its irreversible inhibition of $\mathrm{P} 2 \mathrm{Y}_{12}$ receptor resulting in a slow recovery of platelet function after drug withdrawal [119]. This may initiate bleeding risk within $5-7$ days after 
termination of drug administration especially in patients who need urgent surgical revascularization [119] hence increased transfusion requirements and extended intensive care unit and hospitalization [87, 119]. Therefore, new $\mathrm{P}_{2} \mathrm{Y}_{12}$ antagonists with predictable and efficient inhibition of platelet function in all patients and minor adverse effects were required to be designed.

\subsubsection{Prasugrel}

Prasugrel is a third-generation member of oral thienopyridine [93]. Prasugrel should also undergo metabolism to generate an active form that blocks $\mathrm{P}_{2} \mathrm{Y}_{12}$ selectively and irreversibly [120]. Prasugrel is completely and rapidly absorbed and extensively metabolized in humans [121]. The active metabolite is detectable in plasma after 15 $\mathrm{min}$ and reaches maximum concentration at $30 \mathrm{~min}$ [121]. The cytochrome isoenzymes that are responsible for the generation of the active metabolite are mainly CYP3A and CYP2B6, and to a lesser extent CYP2C9, CYP2C19 and CYP2D6 [122]. Hence the common loss-of-function mutations in CYP2C9 and CYP2C19 which affect clopidogrel, hardly interfere with the formation of the prasugrel active metabolite [117]. Furthermore, intestinal CYP3A contributes more in the generation of an active metabolite as compared with hepatic CYP3A which can explain the rapid appearance of active metabolite in plasma [103]. In addition, prasugrel has been demonstrated to be more rapid, potent and consistent in inhibition of platelet function than clopidogrel [120]. It is transformed into its active metabolite more efficiently as compared with clopidogrel [120]. The maximal effect of prasugrel (60 mg loading dose) began to plateau approximately $1 \mathrm{~h}$ after administration compared to about $4 \mathrm{~h}$ for clopidogrel (300 mg loading dose) [120]. A single oral administration of prasugrel results in a dose-related inhibition of binding 2-MeSADP to platelets in rats about 10 - fold more potent than that of clopidogrel [123].

In stable aspirin-treated patients with coronary artery disease, prasugrel administration also resulted in greater inhibition of platelet aggregation and a lower rate of drug-resistance compared with clopidogrel [124]. Furthermore, it has been reported that active metabolite of prasugrel enhances the inhibitory effect on platelet aggregation of agents that acts via raising cAMP (e.g. prostaglandin $I_{2}$, adenosine and forskolin) [125]. The antiaggregation effects of prasugrel are observed at $30 \mathrm{~min}$, and lasts until $72 \mathrm{~h}$ after administration which demonstrates fast onset and long duration of action of this product [93].

Prasugrel (60 mg loading dose and $10 \mathrm{mg} /$ day maintenance dose) was more potent in inhibition of platelet than clopidogrel (a $600 \mathrm{mg}$ loading dose and $150 \mathrm{mg} /$ day maintenance therapy) [126]. The Trial to Assess Improvement in Therapeutic Outcomes by Optimizing Platelet Inhibition with Prasugrel-Thrombolysis in Myocardial Infarction (TRITON-TIMI) 38, a phase 3 trial involving patients with acute coronary syndromes with scheduled percutaneous coronary intervention, showed that prasugrel administration reduced the rates of ischemic events (e.g. stent thrombosis) compared to clopidogrel however increased the risk of major bleeding with fatal consequences [127]. Prasugrel also inhibits $\mathrm{P}_{2} \mathrm{Y}_{12}$ irreversibly hence the limitation of slow offset of action remains as for clopidogrel [87]. Therefore, prasugrel administration may not efficiently replace clopidogrel.

\subsection{Direct $\mathbf{P 2} \mathbf{Y}_{12}$ inhibitors}

In order to cover these gaps for inhibiting aggregation of platelets by fast-acting and reversible antagonists with short half-lives, direct $\mathrm{P} 2 \mathrm{Y}_{12}$ antagonists have been recently developed. 


\subsubsection{Ticagrelor}

Ticagrelor (AZD6140) is the first oral reversible ADP $\mathrm{P}_{12} \mathrm{Y}_{12}$ receptor antagonist and a member of cyclopentyltriazolopyrimidine class $[128,129]$. It has been reported that the $\mathrm{P}_{2} \mathrm{Y}_{12}$ receptor is targeted by ticagrelor through a mechanism that is not competitive with ADP suggesting the presence of an independent receptor binding site [130]. Iyú et al. have also revealed that ticagrelor mainly affect P2 $\mathrm{Y}_{12}$ receptors [131] with the ability to enhance the inhibitory effect of natural (e.g. vascular prostaglandins $\mathrm{I}_{2}, \mathrm{D}_{2}$ and adenosine) and other (e.g. forskolin) modulators of platelet functions which are raising intracellular cAMP through interaction with $\mathrm{G}_{\mathrm{s}}$-coupled receptor [125]. This may be a great advantage for humans [125].

Further metabolic conversion is not required for ticagrelor as it directly and dose-dependently inhibits $\mathrm{P} 2 \mathrm{Y}_{12}$ receptor with about $95 \%$ inhibition of platelet aggregation within $2-4 \mathrm{~h}$ [128]. Ticagrelor has an early onset of action within $2 \mathrm{~h}$ with no loading dose [132, 133]. Due to a short half-life of about $12 \mathrm{~h}[128,134]$, this product requires to administer twice-daily [132, 133]. Another advantage of ticagrelor compared to thienopyridines family is shorter time for drug offset after ticagrelor withdrawal [128, 132, 133].

Ticagrelor dose of $90 \mathrm{mg}$ twice daily has demonstrated higher and less fluctuated levels of platelet inhibition compared with standard-dose regimens of clopidogrel [133]. Also, single oral dose of ticagrelor up to $400 \mathrm{mg}$ daily was safe and well-tolerated in healthy subjects [128]. While ticagrelor shows similar safety and tolerability to clopidogrel in patients with non-ST-segment elevation acute coronary syndrome, its reversible inhibition of $\mathrm{P} 2 \mathrm{Y}_{12}$ receptor is beneficial in rapid initiation of coronary bypass and surgical procedures after drug discontinuation [134]. Furthermore, PLATelet inhibition and clinical Outcomes (PLATO) trial; phase 3, randomized, double blinded, parallel-group multinationals clinical study, revealed that treatment with ticagrelor as compared to clopidogrel in patients who had an acute coronary syndrome, with or without ST-segment elevation, significantly reduced the mortality rate from vascular causes (e.g. myocardial infarction or stroke) [135]. While the rate of overall bleeding remained the same for both treatments, there was an enhancement in the rate of non-procedure related bleeding in ticagrelor-treated group [135]. However, three subgroups in PLATO trial, including patients enrolled in North America, males $<82 \mathrm{~kg}$ or females $<71 \mathrm{~kg}$ and patients not on lipidlowering medications, did not benefit from ticagrelor treatment [135]. The controversial reports in patients enrolled in North America may be due to geographical differences between populations of patients [135] or pattern of medications practice as aspirin maintenance dose was identified as a potential explanation for the regional differences in North American patients [136]. However this aspect requires more investigation.

Ticagrelor administration (180 mg load and $75 \mathrm{mg}$ per day maintenance dose) also results in more rapid and superior platelet inhibition than high loading dose of clopidogrel (600 $\mathrm{mg}$ load and $90 \mathrm{mg}$ twice a day maintenance dose) in patients with stable coronary artery disease [137]. This inhibition was sustained during the maintenance phase and was faster in offset after discontinuation of treatment [137]. In addition, in patients with acute coronary syndrome managed a non-invasive treatment strategy, more intense $\mathrm{P} 2 \mathrm{Y}_{12}$ receptor inhibition with ticagrelor achieved a clinically relevant reduction in ischemic events and mortality but with no major increase in bleeding compared with clopidogrel [138].

It has been also demonstrated that the greater antiplatelet effect of ticagrelor compared to clopidogrel is irrespective of CYP2C19 and ABCB1 polymorphism [139, 140]. Although CYP2C19 genotype affected the antiplatelet effect of clopidogrel, no effect was observed during ticagrelor therapy [139]. Hence administration of 
ticagrelor instead of clopidogrel eliminates the need for genetic testing before dual antiplatelet treatment with aspirin [140]. Ticagrelor treatment also overcomes nonresponsiveness to clopidogrel since its antiplatelet effect is similar in responders and nonresponders [141].

There were however higher rates of dyspnoea, hypotension, and nausea in patients treated with ticagrelor [134]. The respiratory side effects occurring after oral ticagrelor or intravenous cangrelor may be due to the development of mild asymptomatic thrombotic thrombocytopenic purpura advancing to more acute scenario including fluid retention and dyspnoea because of the reversible nature of these drugs [142]. Dyspnoea is often arising during the first week of treatment with ticagrelor at mild or moderate level of severity however usually transient in spite of continuing therapy [143]. The more frequent incidence of dyspnoea may be due to modulation of adenosine metabolism [134]. However further studies are required to investigate ticagrelor side effects.

\subsubsection{Cangrelor}

Cangrelor (AR-C69931MX) is a potent, selective and competitive $\mathrm{P}_{2} \mathrm{Y}_{12}$ receptor antagonist that is administered intravenously $[129,144]$. Cangrelor is an analog of ATP, natural $\mathrm{P}_{2} \mathrm{Y}_{12}$ receptor antagonist, with inhibitory effect in a dose-dependent manner [129, 145]. It has been also reported that cangrelor enhances platelet cAMP level through unidentified platelet $\mathrm{G}_{\mathrm{s}}$ protein-coupled receptor mediating inhibition of platelet function [146]. Whereas, similar pattern of action to ticagrelor in promoting the inhibitory effect of natural modulators of platelet functions or other agents that act via increasing cAMP with the main effect of cangrelor on $\mathrm{P} 2 \mathrm{Y}_{12}$ receptors was reported by another group $[125,131]$

Cangrelor acts directly on the $\mathrm{P} 2 \mathrm{Y}_{12}$ receptor with a rapid onset of action (approximately 15 [144] to 30 $\mathrm{min}$ ), rapidly achieves steady-state inhibition of platelet aggregation with a half-life of approximately $2-5$ min [145] and clearance at steady state of $12.7 \mathrm{ml} / \mathrm{min}$ per $\mathrm{kg}$ [147]. In addition, cangrelor does not require to be metabolized to form active product and directly inhibits the $\mathrm{P}_{2} \mathrm{Y}_{12}$ receptor. Therefore cangrelor has a rapid reversal effect, as $70 \%$ of patients recovered more than $60 \%$ of baseline aggregation response after $1 \mathrm{~h}$ of termination of administration [145]. This is a great advantage in patients with hemorrhagic complications or required surgical intervention [145]. In patients undergoing percutaneous coronary intervention, intravenous cangrelor (4 $\mu \mathrm{g} / \mathrm{kg}$ per minute) also compares favourably with abciximab (a glycoprotein IIb/IIIa receptor antagonist) with acceptable bleeding risk and adverse cardiac events while reaching rapid, reversible inhibition of platelet aggregation with less side effect of prolonged bleeding time [144]. In addition, acceptable safety, tolerability and efficacy of adjunctive cangrelor administration with fibrinolysis suggested the potential of this combination in the treatment of acute myocardial infarction [148].

Following acute in-hospital, patients receive clopidogrel treatment to prevent further cardiovascular complications [149]. To achieve sustained platelet $\mathrm{P}_{2} \mathrm{Y}_{12}$ inhibition in patients treated with cangrelor, clopidogrel should be administered when the cangrelor treatment is terminated since simultaneous administration of both drugs prevent the effect of a $600 \mathrm{mg}$ loading dose of clopidogrel $4-6 \mathrm{~h}$ later [149]. An in vitro study showed that cangrelor modulates the platelet function inhibitory effect of the active metabolites of clopidogrel or prasugrel hence careful consideration should be given for co-administration of these drugs [150].

Periprocedural cangrelor during percutaneous coronary intervention followed by $600 \mathrm{mg}$ of clopidogrel was not superior to placebo followed by $600 \mathrm{mg}$ of clopidogrel in reducing primary end point of death from any 
cause including myocardial infarction, or ischemia-driven revascularization at $48 \mathrm{~h}$, whereas the prespecified secondary end points of stent thrombosis and death were lower in the cangrelor group, with no significant increase in the rate of transfusion [151]. Administration of cangrelor $30 \mathrm{~min}$ before percutaneous coronary intervention for $2 \mathrm{~h}$ after percutaneous coronary intervention however was not superior to an oral loading dose of $600 \mathrm{mg}$ of clopidogrel, administered $30 \mathrm{~min}$ prior to the procedure, in decreasing the composite end point of death from any cause, myocardial infarction, or ischemia-driven revascularization at 48 hours [152]. Hence implication of cangelor in routine practice may be questionable.

On the other hand, study of bridging antiplatelet therapy with cangrelor in patients undergoing cardiac surgery revealed that among patients who discontinue thienopyridine therapy prior to cardiac surgery, the use of cangrelor for at least $48 \mathrm{~h}$ compared with placebo resulted in a higher rate of maintenance of platelet inhibition with low risk of thrombotic events and no significant excess bleeding complications [153]. Therefore, intravenous cangrelor may be a feasible management strategy in patients waiting for cardiac surgery who require prolonged platelet $\mathrm{P} 2 \mathrm{Y}_{12}$ inhibition after thienopyridine discontinuation [153]. However more investigation is required to study cangrelor ADP blockade effects as an antiplatelet therapy.

\subsubsection{Elinogrel}

Elinogrel (PRT060128) is an investigational, potent, competitive, direct acting reversible $\mathrm{P}_{12} \mathrm{Y}_{12}$ receptor inhibitor with the fast onset and offset of action that can be administered both orally and intravenously [154, 155]. Elinogrel belongs to the family of quinazolinedione [155]. Administration of elinogrel intravenously showed well-tolerability and safety, and achieves immediate and high level of platelet inhibition [154]. The average terminal half-life at the $40 \mathrm{mg}$ elinogrel administered intravenously was about $11 \mathrm{~h}$ and maximum platelet inhibition achieved at $20 \mathrm{~min}$ [154]. The inhibitory effect of platelet was completely reversible within 8 $-24 \mathrm{~h}$ of elinogrel administration $[155,156]$. This is an advantage in reducing bleeding side effect in the setting of urgent surgery and avoiding unnecessary delay before nonurgent surgery [157]. Preliminary data on safety and tolerability of single dose intravenous loading doses $(10-60 \mathrm{mg})$ of elinogrel have recommended this treatment as an adjunctive therapy for primary percutaneous coronary intervention for ST-elevation myocardial infarction [156].

Pharmacologically, the intravenous and oral forms of elinogrel are identical [157]. Therefore the potential for the vulnerability associated with the transition from one intravenous to a different oral $\mathrm{P} 2 \mathrm{Y}_{12}$ receptor inhibitor may be avoided [157]. It has been suggested that one single $60 \mathrm{mg}$ oral dose of elinogrel overcomes, reversibly, the high platelet reactivity due to CYP2C19*2 genotype on standard dual-antiplatelet therapy with aspirin and clopidogrel [158].

Currently, a phase II randomized, double-blind, clopidogrel-controlled trial is undergoing to assess the safety, tolerability and preliminary efficacy of elinogrel (intravenous and oral) administration compared with clopidogrel in patients undergoing nonurgent percutaneous coronary intervention [157].

Elinogrel has been indicated to possess greater therapeutic index (less bleeding) compared with that in $\mathrm{P} 2 \mathrm{Y}_{12}{ }^{-/-}$mice which may be because of the reversible and competitive nature of this antiplatelet drug [159]. However, thienopyridines have decreased therapeutic index (increased bleeding) possibly due to $\mathrm{P}_{2} \mathrm{Y}_{12^{-}}$ independent off-targeting effects at the vessel wall [159]. Furthermore, animal studies have revealed that equivalent, maximal levels of platelet aggregation inhibition in response to ADP was achieved by elinogrel (60 
$\mathrm{mg} / \mathrm{kg}$ ) whereas clopidogrel $\left(50 \mathrm{mg} / \mathrm{kg}\right.$ ) failed to reproduce the phenotype associated with $\mathrm{P} 2 \mathrm{Y}_{12}$ deficiency [160]. In addition, clopidogrel is not able to block the inducible pool of P2 $\mathrm{Y}_{12}$ exists on platelets, which can be exposed upon platelet activation in response to strong agonist and contributes to thrombosis, whereas elinogrel can block this pool [160]. Hence pharmacological properties of elinogrel make this drug an attractive antiplatelet agent. However more extensive clinical investigations are required to determine the efficacy and safety of this product.

\section{Concluding remarks}

In summary, purinergic $\mathrm{P} 2 \mathrm{Y}_{12}$ receptor, a member of $\mathrm{G}$ protein-coupled receptors, is essential in normal hemostatic process and pathophysiological conditions. Understanding of the structure and the signaling pathways of the $\mathrm{P} 2 \mathrm{Y}_{12}$ receptor is pivotal to identify ideal targets for antithrombotic drugs. The 342 amino acid residues $\mathrm{P}_{2} \mathrm{Y}_{12}$ receptor structure contains 7 hydrophobic transmembrane regions in conjunction with 3 extracellular loops and 3 intracellular loops with 10 cysteine residues. Stimulation of P2Y 12 by ADP results in coupling this receptor with $\alpha_{\mathrm{i} 2}$ subunit of $\mathrm{G}$ protein hence activation of various signaling pathways responsible for amplification of platelet activation and stabilization of platelet aggregates. Deficiency of this receptor results in platelet dysfunction and bleeding diathesis indicating the possibility of targeting this receptor as an antithrombotic drug. Selective tissue distribution of $\mathrm{P} 2 \mathrm{Y}_{12}$ receptor compared with other purinergic receptors, e.g. $\mathrm{P} 2 \mathrm{Y}_{1}$, also makes this receptor a great advantage as a target for anti-thrombotic therapy. Current inhibitors of $\mathrm{P}_{2} \mathrm{Y}_{12}$ receptor are classified into indirect inhibitors or thienopyridines family (ticlopidine, clopidogrel and prasugrel), and direct $\mathrm{P}_{2} \mathrm{Y}_{12}$ inhibitors (ticagrelor, cangrelor and elinogrel). Clopidogrel is the most commonly prescribed inhibitor of $\mathrm{P}_{2} \mathrm{Y}_{12}$ receptor. However due to therapeutic limitations of this prodrug, such as slow onset and offset and interindividual variability, direct inhibitors of $\mathrm{P}_{2} \mathrm{Y}_{12}$ receptor are currently under investigation.

\section{Declaration of interest}

The authors report no declarations of interest. 


\section{References}

1. Gachet C. The platelet P2 receptors as molecular targets for old and new antiplatelet drugs. Pharmacol Ther. 2005; 108:180-92.

2. Australian Institute of Health and Welfare (AIHW). Heart, stroke and vascular diseases, Australian facts 2004.

Cardiovascular Disease Series No. 22. 2004, Canberra: AIHW and National Heart Foundation of Australia.

3. Savage B, Almus-Jacobs F, Ruggeri ZM. Specific synergy of multiple substrate-receptor interactions in platelet thrombus formation under flow. Cell. 1998; 94:657-66.

4. Cattaneo M, Zighetti ML, Lombardi R, Martinez C, Lecchi A, Conley PB, et al. Molecular bases of defective signal transduction in the platelet P2Y12 receptor of a patient with congenital bleeding. Proc Natl Acad Sci U S A. $2003 ; 100: 1978-83$.

5. Dorsam RT,Kunapuli SP. Central role of the P2Y12 receptor in platelet activation. J Clin Invest. 2004; 113:340-5.

6. Kahner BN, Shankar H, Murugappan S, Prasad GL, Kunapuli SP. Nucleotide receptor signaling in platelets. J Thromb Haemost. 2006; 4:2317-26.

7. Von Kugelgen I. Pharmacological profiles of cloned mammalian P2Y-receptor subtypes. Pharmacol Ther. 2006; 110:415-32.

8. Ralevic V,Burnstock G. Receptors for purines and pyrimidines. Pharmacol Rev. 1998; 50:413-92.

9. Khakh BS, Burnstock G, Kennedy C, King BF, North RA, Seguela P, et al. International union of pharmacology. XXIV. Current status of the nomenclature and properties of P2X receptors and their subunits. Pharmacol Rev. 2001; 53:107-18.

10. Abbracchio MP, Boeynaems JM, Barnard EA, Boyer JL, Kennedy C, Miras-Portugal MT, et al. Characterization of the UDP-glucose receptor (re-named here the P2Y14 receptor) adds diversity to the P2Y receptor family. Trends Pharmacol Sci. 2003; 24:52-5.

11. Communi D, Janssens R, Suarez-Huerta N, Robaye B, Boeynaems JM. Advances in signalling by extracellular nucleotides. the role and transduction mechanisms of P2Y receptors. Cell Signal. 2000; 12:351-60.

12. Nicholas RA. Identification of the P2Y(12) receptor: a novel member of the P2Y family of receptors activated by extracellular nucleotides. Mol Pharmacol. 2001; 60:416-20.

13. Dubyak GR. Knock-out mice reveal tissue-specific roles of P2Y receptor subtypes in different epithelia. Mol Pharmacol. 2003; 63:773-6.

14. Wang L, Ostberg O, Wihlborg AK, Brogren H, Jern S, Erlinge D. Quantification of ADP and ATP receptor expression in human platelets. J Thromb Haemost. 2003; 1:330-6.

15. Leon C, Hechler B, Freund M, Eckly A, Vial C, Ohlmann P, et al. Defective platelet aggregation and increased resistance to thrombosis in purinergic P2Y(1) receptor-null mice. J Clin Invest. 1999; 104:1731-7.

16. Hechler B, Eckly A, Ohlmann P, Cazenave JP, Gachet C. The P2Y1 receptor, necessary but not sufficient to support full ADP-induced platelet aggregation, is not the target of the drug clopidogrel. Br J Haematol. 1998; 103:858-66.

17. Hechler B, Leon C, Vial C, Vigne P, Frelin C, Cazenave JP, et al. The P2Y1 receptor is necessary for adenosine 5'-diphosphate-induced platelet aggregation. Blood. 1998; 92:152-9.

18. Savi P, Beauverger P, Labouret C, Delfaud M, Salel V, Kaghad M, et al. Role of P2Y1 purinoceptor in ADPinduced platelet activation. FEBS Lett. 1998; 422:291-5. 
19. Hollopeter G, Jantzen HM, Vincent D, Li G, England L, Ramakrishnan V, et al. Identification of the platelet ADP receptor targeted by antithrombotic drugs. Nature. 2001; 409:202-7.

20. Foster CJ, Prosser DM, Agans JM, Zhai Y, Smith MD, Lachowicz JE, et al. Molecular identification and characterization of the platelet ADP receptor targeted by thienopyridine antithrombotic drugs. J Clin Invest. 2001; 107:1591-8.

21. Takasaki J, Kamohara M, Saito T, Matsumoto M, Matsumoto S, Ohishi T, et al. Molecular cloning of the platelet P2T(AC) ADP receptor: pharmacological comparison with another ADP receptor, the P2Y(1) receptor. Mol Pharmacol. 2001; 60:432-9.

22. Kauffenstein G, Hechler B, Cazenave JP, Gachet C. Adenine triphosphate nucleotides are antagonists at the P2Y receptor. J Thromb Haemost. 2004; 2:1980-8.

23. Bodor ET, Waldo GL, Hooks SB, Corbitt J, Boyer JL, Harden TK. Purification and functional reconstitution of the human P2Y12 receptor. Mol Pharmacol. 2003; 64:1210-6.

24. Savi P, Zachayus JL, Delesque-Touchard N, Labouret C, Herve C, Uzabiaga MF, et al. The active metabolite of Clopidogrel disrupts P2Y12 receptor oligomers and partitions them out of lipid rafts. Proc Natl Acad Sci U S A. $2006 ; 103: 11069-74$

25. Ding Z, Kim S, Dorsam RT, Jin J, Kunapuli SP. Inactivation of the human P2Y12 receptor by thiol reagents requires interaction with both extracellular cysteine residues, Cys17 and Cys270. Blood. 2003; 101:3908-14.

26. Zhong X, Kriz R, Seehra J, Kumar R. N-linked glycosylation of platelet P2Y12 ADP receptor is essential for signal transduction but not for ligand binding or cell surface expression. FEBS Lett. 2004; 562:111-7.

27. Gilman AG. G proteins: transducers of receptor-generated signals. Annu Rev Biochem. 1987; 56:615-49.

28. Woulfe D, Yang J, Brass L. ADP and platelets: the end of the beginning. J Clin Invest. 2001; 107:1503-5.

29. Williams AG, Woolkalis MJ, Poncz M, Manning DR, Gewirtz AM, Brass LF. Identification of the pertussis toxin-sensitive $\mathrm{G}$ proteins in platelets, megakaryocytes, and human erythroleukemia cells. Blood. 1990; 76:72130 .

30. Gagnon AW, Manning DR, Catani L, Gewirtz A, Poncz M, Brass LF. Identification of Gz alpha as a pertussis toxin-insensitive $\mathrm{G}$ protein in human platelets and megakaryocytes. Blood. 1991; 78:1247-53.

31. Woulfe D, Jiang H, Mortensen R, Yang J, Brass LF. Activation of Rap1B by G(i) family members in platelets. J Biol Chem. 2002; 277:23382-90.

32. Jin J,Kunapuli SP. Coactivation of two different G protein-coupled receptors is essential for ADP-induced platelet aggregation. Proc Natl Acad Sci U S A. 1998; 95:8070-4.

33. Offermanns S, Hu YH, Simon MI. Galpha12 and galpha13 are phosphorylated during platelet activation. J Biol Chem. 1996; 271:26044-8.

34. Offermanns S, Toombs CF, Hu YH, Simon MI. Defective platelet activation in G alpha(q)-deficient mice. Nature. 1997; 389:183-6.

35. Yang J, Wu J, Kowalska MA, Dalvi A, Prevost N, O'brien PJ, et al. Loss of signaling through the G protein, Gz, results in abnormal platelet activation and altered responses to psychoactive drugs. Proc Natl Acad Sci U S A. 2000; 97:9984-9.

36. Jantzen HM, Milstone DS, Gousset L, Conley PB, Mortensen RM. Impaired activation of murine platelets lacking G alpha(i2). J Clin Invest. 2001; 108:477-83. 
37. Ohlmann P, Laugwitz KL, Nurnberg B, Spicher K, Schultz G, Cazenave JP, et al. The human platelet ADP receptor activates Gi2 proteins. Biochem J. 1995; 312 ( Pt 3):775-9.

38. Weber AA, Hohlfeld T, Schror K. cAMP is an important messenger for ADP-induced platelet aggregation. Platelets. 1999; 10:238-41.

39. Yang J, Wu J, Jiang H, Mortensen R, Austin S, Manning DR, et al. Signaling through Gi family members in platelets. Redundancy and specificity in the regulation of adenylyl cyclase and other effectors. J Biol Chem. 2002; 277:46035-42.

40. Nguyen TA, Diodati JG, Pharand C. Resistance to clopidogrel: a review of the evidence. J Am Coll Cardiol. 2005; 45:1157-64.

41. Waldmann R, Nieberding M, Walter U. Vasodilator-stimulated protein phosphorylation in platelets is mediated by cAMP- and cGMP-dependent protein kinases. Eur J Biochem. 1987; 167:441-8.

42. Horstrup K, Jablonka B, Honig-Liedl P, Just M, Kochsiek K, Walter U. Phosphorylation of focal adhesion vasodilator-stimulated phosphoprotein at Ser157 in intact human platelets correlates with fibrinogen receptor inhibition. Eur J Biochem. 1994; 225:21-7.

43. Aleil B, Ravanat C, Cazenave JP, Rochoux G, Heitz A, Gachet C. Flow cytometric analysis of intraplatelet VASP phosphorylation for the detection of clopidogrel resistance in patients with ischemic cardiovascular diseases. J Thromb Haemost. 2005; 3:85-92.

44. Geiger J, Teichmann L, Grossmann R, Aktas B, Steigerwald U, Walter U, et al. Monitoring of clopidogrel action: comparison of methods. Clin Chem. 2005; 51:957-65.

45. Trumel C, Payrastre B, Plantavid M, Hechler B, Viala C, Presek P, et al. A key role of adenosine diphosphate in the irreversible platelet aggregation induced by the PAR1-activating peptide through the late activation of phosphoinositide 3-kinase. Blood. 1999; 94:4156-65.

46. Kauffenstein G, Bergmeier W, Eckly A, Ohlmann P, Leon C, Cazenave JP, et al. The P2Y(12) receptor induces platelet aggregation through weak activation of the alpha(IIb)beta(3) integrin--a phosphoinositide 3kinase-dependent mechanism. FEBS Lett. 2001; 505:281-90.

47. Lova P, Paganini S, Hirsch E, Barberis L, Wymann M, Sinigaglia F, et al. A selective role for phosphatidylinositol 3,4,5-trisphosphate in the Gi-dependent activation of platelet Rap1B. J Biol Chem. 2003; 278:131-8.

48. Cosemans JM, Munnix IC, Wetzker R, Heller R, Jackson SP, Heemskerk JW. Continuous signaling via PI3K isoforms beta and gamma is required for platelet ADP receptor function in dynamic thrombus stabilization. Blood. 2006; 108:3045-52.

49. Jackson SP, Schoenwaelder SM, Goncalves I, Nesbitt WS, Yap CL, Wright CE, et al. PI 3-kinase p110beta: a new target for antithrombotic therapy. Nat Med. 2005; 11:507-14.

50. Hirsch E, Bosco O, Tropel P, Laffargue M, Calvez R, Altruda F, et al. Resistance to thromboembolism in PI3Kgamma-deficient mice. FASEB J. 2001; 15:2019-21.

51. Vanhaesebroeck B,Waterfield MD. Signaling by distinct classes of phosphoinositide 3-kinases. Exp Cell Res. 1999; 253:239-54.

52. Lova P, Paganini S, Sinigaglia F, Balduini C, Torti M. A Gi-dependent pathway is required for activation of the small GTPase Rap1B in human platelets. J Biol Chem. 2002; 277:12009-15. 
53. Larson MK, Chen H, Kahn ML, Taylor AM, Fabre JE, Mortensen RM, et al. Identification of P2Y12dependent and -independent mechanisms of glycoprotein VI-mediated Rap1 activation in platelets. Blood. 2003; 101:1409-15.

54. Bertoni A, Tadokoro S, Eto K, Pampori N, Parise LV, White GC, et al. Relationships between Rap1b, affinity modulation of integrin alpha IIbbeta 3, and the actin cytoskeleton. J Biol Chem. 2002; 277:25715-21.

55. Bos JL, De Rooij J, Reedquist KA. Rap1 signalling: adhering to new models. Nat Rev Mol Cell Biol. 2001; 2:369-77.

56. Yart A, Roche S, Wetzker R, Laffargue M, Tonks N, Mayeux P, et al. A function for phosphoinositide 3kinase beta lipid products in coupling beta gamma to Ras activation in response to lysophosphatidic acid. J Biol Chem. 2002; 277:21167-78.

57. Kim S, Jin J, Kunapuli SP. Akt activation in platelets depends on Gi signaling pathways. J Biol Chem. 2004; 279:4186-95.

58. Burgering BM,Coffer PJ. Protein kinase B (c-Akt) in phosphatidylinositol-3-OH kinase signal transduction. Nature. 1995; 376:599-602.

59. Kroner C, Eybrechts K, Akkerman JW. Dual regulation of platelet protein kinase B. J Biol Chem. 2000; 275:27790-8.

60. Stokoe D, Stephens LR, Copeland T, Gaffney PR, Reese CB, Painter GF, et al. Dual role of phosphatidylinositol-3,4,5-trisphosphate in the activation of protein kinase B. Science. 1997; 277:567-70.

61. Toker A,Newton AC. Akt/protein kinase B is regulated by autophosphorylation at the hypothetical PDK-2 site. J Biol Chem. 2000; 275:8271-4.

62. Troussard AA, Mawji NM, Ong C, Mui A, St -Arnaud R, Dedhar S. Conditional knock-out of integrin-linked kinase demonstrates an essential role in protein kinase B/Akt activation. J Biol Chem. 2003; 278:22374-8.

63. Woulfe D, Jiang H, Morgans A, Monks R, Birnbaum M, Brass LF. Defects in secretion, aggregation, and thrombus formation in platelets from mice lacking Akt2. J Clin Invest. 2004; 113:441-50.

64. Shankar H, Kahner BN, Prabhakar J, Lakhani P, Kim S, Kunapuli SP. G-protein-gated inwardly rectifying potassium channels regulate ADP-induced cPLA2 activity in platelets through Src family kinases. Blood. 2006; 108:3027-34

65. Shankar H, Murugappan S, Kim S, Jin J, Ding Z, Wickman K, et al. Role of G protein-gated inwardly rectifying potassium channels in P2Y12 receptor-mediated platelet functional responses. Blood. 2004; 104:133543.

66. Ma YC, Huang J, Ali S, Lowry W, Huang XY. Src tyrosine kinase is a novel direct effector of G proteins. Cell. 2000; 102:635-46.

67. Pumiglia KM,Feinstein MB. Thrombin and thrombin receptor agonist peptide induce tyrosine phosphorylation and tyrosine kinases in the platelet cytoskeleton. Translocation of pp60c-src and integrin alpha IIb beta 3 (glycoprotein IIb/IIIa) is not required for aggregation, but is dependent on formation of large aggregate structures. Biochem J. 1993; 294 ( Pt 1):253-60.

68. Horvath AR, Muszbek L, Kellie S. Translocation of pp60c-src to the cytoskeleton during platelet aggregation. EMBO J. 1992; 11:855-61. 
69. Dorsam RT, Kim S, Murugappan S, Rachoor S, Shankar H, Jin J, et al. Differential requirements for calcium and Src family kinases in platelet GPIIb/IIIa activation and thromboxane generation downstream of different Gprotein pathways. Blood. 2005; 105:2749-56.

70. Hardy AR, Jones ML, Mundell SJ, Poole AW. Reciprocal cross-talk between P2Y1 and P2Y12 receptors at the level of calcium signaling in human platelets. Blood. 2004; 104:1745-52.

71. Garcia A, Quinton TM, Dorsam RT, Kunapuli SP. Src family kinase-mediated and Erk-mediated thromboxane A2 generation are essential for VWF/GPIb-induced fibrinogen receptor activation in human platelets. Blood. 2005; 106:3410-4.

72. Li Z, Xi X, Du X. A mitogen-activated protein kinase-dependent signaling pathway in the activation of platelet integrin alpha IIbbeta3. J Biol Chem. 2001; 276:42226-32.

73. Papkoff J, Chen RH, Blenis J, Forsman J. p42 mitogen-activated protein kinase and p90 ribosomal S6 kinase are selectively phosphorylated and activated during thrombin-induced platelet activation and aggregation. Mol Cell Biol. 1994; 14:463-72.

74. Garcia A, Shankar H, Murugappan S, Kim S, Kunapuli SP. Regulation and functional consequences of ADP receptor-mediated ERK2 activation in platelets. Biochem J. 2007; 404:299-308.

75. Jupp OJ, Vandenabeele P, Macewan DJ. Distinct regulation of cytosolic phospholipase A2 phosphorylation, translocation, proteolysis and activation by tumour necrosis factor-receptor subtypes. Biochem J. 2003; $374: 453$ 61.

76. Lin LL, Lin AY, Knopf JL. Cytosolic phospholipase A2 is coupled to hormonally regulated release of arachidonic acid. Proc Natl Acad Sci U S A. 1992; 89:6147-51.

77. Cattaneo M. Molecular defects of the platelet P2 receptors. Purinergic Signal. 2011; 7:333-9.

78. Cattaneo M,Gachet C. ADP receptors and clinical bleeding disorders. Arterioscler Thromb Vasc Biol. 1999; $19: 2281-5$.

79. Fontana G, Ware J, Cattaneo M. Haploinsufficiency of the platelet P2Y12 gene in a family with congenital bleeding diathesis. Haematologica. 2009; 94:581-4.

80. Shiraga M, Miyata S, Kato H, Kashiwagi H, Honda S, Kurata Y, et al. Impaired platelet function in a patient with P2Y12 deficiency caused by a mutation in the translation initiation codon. J Thromb Haemost. 2005; $3: 2315-23$.

81. Daly ME, Dawood BB, Lester WA, Peake IR, Rodeghiero F, Goodeve AC, et al. Identification and characterization of a novel P2Y12 variant in a patient diagnosed with type 1 von Willebrand disease in the European MCMDM-1VWD study. Blood. 2009; 113:4110-3.

82. Nurden P, Savi P, Heilmann E, Bihour C, Herbert JM, Maffrand JP, et al. An inherited bleeding disorder linked to a defective interaction between ADP and its receptor on platelets. Its influence on glycoprotein IIb-IIIa complex function. J Clin Invest. 1995; 95:1612-22.

83. Cattaneo M, Lecchi A, Lombardi R, Gachet C, Zighetti ML. Platelets from a patient heterozygous for the defect of P2CYC receptors for ADP have a secretion defect despite normal thromboxane A2 production and normal granule stores: further evidence that some cases of platelet 'primary secretion defect' are heterozygous for a defect of P2CYC receptors. Arterioscler Thromb Vasc Biol. 2000; 20:E101-6. 
84. Cattaneo M, Lecchi A, Randi AM, Mcgregor JL, Mannucci PM. Identification of a new congenital defect of platelet function characterized by severe impairment of platelet responses to adenosine diphosphate. Blood. 1992; 80:2787-96.

85. Humbert M, Nurden P, Bihour C, Pasquet JM, Winckler J, Heilmann E, et al. Ultrastructural studies of platelet aggregates from human subjects receiving clopidogrel and from a patient with an inherited defect of an ADP-dependent pathway of platelet activation. Arterioscler Thromb Vasc Biol. 1996; 16:1532-43.

86. Zighetti ML, Carpani G, Sinigaglia E, Cattaneo M. Usefulness of a flow cytometric analysis of intraplatelet vasodilator-stimulated phosphoprotein phosphorylation for the detection of patients with genetic defects of the platelet P2Y(12) receptor for ADP. J Thromb Haemost. 2010; 8:2332-4.

87. Cattaneo M. New P2Y(12) inhibitors. Circulation. 2010; 121:171-9.

88. Gent M, Blakely JA, Easton JD, Ellis DJ, Hachinski VC, Harbison JW, et al. The Canadian American Ticlopidine Study (CATS) in thromboembolic stroke. Lancet. 1989; 1:1215-20.

89. Bertrand ME, Legrand V, Boland J, Fleck E, Bonnier J, Emmanuelson H, et al. Randomized multicenter comparison of conventional anticoagulation versus antiplatelet therapy in unplanned and elective coronary stenting. The full anticoagulation versus aspirin and ticlopidine (fantastic) study. Circulation. 1998; 98:1597603.

90. Schomig A, Neumann FJ, Kastrati A, Schuhlen H, Blasini R, Hadamitzky M, et al. A randomized comparison of antiplatelet and anticoagulant therapy after the placement of coronary-artery stents. N Engl J Med. 1996; 334:1084-9.

91. Leon MB, Baim DS, Popma JJ, Gordon PC, Cutlip DE, Ho KK, et al. A clinical trial comparing three antithrombotic-drug regimens after coronary-artery stenting. Stent Anticoagulation Restenosis Study Investigators. N Engl J Med. 1998; 339:1665-71.

92. Urban P, Macaya C, Rupprecht HJ, Kiemeneij F, Emanuelsson H, Fontanelli A, et al. Randomized evaluation of anticoagulation versus antiplatelet therapy after coronary stent implantation in high-risk patients: the multicenter aspirin and ticlopidine trial after intracoronary stenting (MATTIS). Circulation. 1998; 98:212632.

93. Angiolillo DJ. ADP receptor antagonism: what's in the pipeline? Am J Cardiovasc Drugs. 2007; 7:423-32.

94. Bertrand ME, Rupprecht HJ, Urban P, Gershlick AH. Double-blind study of the safety of clopidogrel with and without a loading dose in combination with aspirin compared with ticlopidine in combination with aspirin after coronary stenting : the clopidogrel aspirin stent international cooperative study (CLASSICS). Circulation. 2000; 102:624-9.

95. Mega JL, Close SL, Wiviott SD, Shen L, Walker JR, Simon T, et al. Genetic variants in ABCB1 and CYP2C19 and cardiovascular outcomes after treatment with clopidogrel and prasugrel in the TRITON-TIMI 38 trial: a pharmacogenetic analysis. Lancet. 2010; 376:1312-9.

96. Byrne RA, Schulz S, Mehilli J, Iijima R, Massberg S, Neumann FJ, et al. Rationale and design of a randomized, double-blind, placebo-controlled trial of 6 versus 12 months clopidogrel therapy after implantation of a drug-eluting stent: The Intracoronary Stenting and Antithrombotic Regimen: Safety And EFficacy of 6 Months Dual Antiplatelet Therapy After Drug-Eluting Stenting (ISAR-SAFE) study. Am Heart J. 2009; 157:620-4. e2. 
97. Savi P, Nurden P, Nurden AT, Levy-Toledano S, Herbert JM. Clopidogrel: a review of its mechanism of action. Platelets. 1998; 9:251-5.

98. Logman JF, Heeg BM, Herlitz J, Van Hout BA. Costs and consequences of clopidogrel versus aspirin for secondary prevention of ischaemic events in (high-risk) atherosclerotic patients in Sweden: a lifetime model based on the CAPRIE trial and high-risk CAPRIE subpopulations. Appl Health Econ Health Policy. 2010; 8:251-65.

99. Kolm P, Yuan Y, Veledar E, Mehta SR, O'brien JA, Weintraub WS. Cost-effectiveness of clopidogrel in acute coronary syndromes in Canada: a long-term analysis based on the CURE trial. Can J Cardiol. 2007; 23:1037-42.

100. Berg J, Fidan D, Lindgren P. Cost-effectiveness of clopidogrel treatment in percutaneous coronary intervention: a European model based on a meta-analysis of the PCI-CURE, CREDO and PCI-CLARITY trials. Curr Med Res Opin. 2008; 24:2089-101.

101. Cushing DJ, Souney PF, Cooper WD, Mosher GL, Adams MP, Machatha S, et al. Assessment of the pharmacokinetics and platelet aggregation inhibitory effects of a novel intravenous formulation of clopidogrel in humans. Clin Exp Pharmacol Physiol. 2011.

102. Angiolillo DJ,Ferreiro JL. Platelet adenosine diphosphate P2Y12 receptor antagonism: benefits and limitations of current treatment strategies and future directions. Rev Esp Cardiol. 2010; 63:60-76.

103. Farid NA, Kurihara A, Wrighton SA. Metabolism and disposition of the thienopyridine antiplatelet drugs ticlopidine, clopidogrel, and prasugrel in humans. J Clin Pharmacol. 2010; 50:126-42.

104. Patrono C, Bachmann F, Baigent C, Bode C, De Caterina R, Charbonnier B, et al. Expert consensus document on the use of antiplatelet agents. The task force on the use of antiplatelet agents in patients with atherosclerotic cardiovascular disease of the European society of cardiology. Eur Heart J. 2004; 25:166-81.

105. Kushner FG, Smith SC, King SB, Anderson JL, Antman EM, Bailey SR, et al. 2009 Focused Updates: ACC/AHA Guidelines for the Management of Patients With ST-Elevation Myocardial Infarction (Updating the 2004 Guideline and 2007 Focused Update) and ACC/AHA/SCAI Guidelines on Percutaneous Coronary Intervention (Updating the 2005 Guideline and 2007 Focused Update) A Report of the American College of Cardiology Foundation/American Heart Association Task Force on Practice Guidelines. Circulation. 2009; 120:2271-306.

106. PLAVIX (clopidogrel bisulfate) Tablets [Prescribing Information] [internet]. Bristol-Myers Squibb/Sanofi Pharmaceuticals Partnership. 2010 - [cited 2012 Feb 7]. Available from: http://products.sanofiaventis.us/PLAVIX/PLAVIX.html.

107. Angiolillo DJ, Fernandez-Ortiz A, Bernardo E, Ramirez C, Sabate M, Banuelos C, et al. High clopidogrel loading dose during coronary stenting: effects on drug response and interindividual variability. European Heart Journal. 2004; 25:1903-10.

108. Patti G, Colonna G, Pasceri V, Pepe LL, Montinaro A, Di Sciascio G. Randomized trial of high loading dose of clopidogrel for reduction of periprocedural myocardial infarction in patients undergoing coronary intervention - Results from the ARMYDA-2 (Antiplatelet therapy for reduction of MYocardial Damage during Angioplasty) study. Circulation. 2005; 111:2099-106.

109. Cuisset T, Frere C, Quilici J, Morange PE, Nait-Saidi L, Carvajal J, et al. Benefit of a 600-mg loading dose of clopidogrel on platelet reactivity and clinical outcomes in patients with non-ST-segment elevation acute 
coronary syndrome undergoing coronary stenting. Journal of the American College of Cardiology. 2006; 48:1339-45.

110. Wiviott SD,Antman EM. Clopidogrel resistance: a new chapter in a fast-moving story. Circulation. 2004; 109:3064-7.

111. Gurbel PA, Bliden KP, Hiatt BL, O'connor CM. Clopidogrel for coronary stenting: response variability, drug resistance, and the effect of pretreatment platelet reactivity. Circulation. 2003; 107:2908-13.

112. Snoep JD, Hovens MM, Eikenboom JC, Van Der Bom JG, Jukema JW, Huisman MV. Clopidogrel nonresponsiveness in patients undergoing percutaneous coronary intervention with stenting: a systematic review and meta-analysis. Am Heart J. 2007; 154:221-31.

113. Lau WC, Gurbel PA, Watkins PB, Neer CJ, Hopp AS, Carville DG, et al. Contribution of hepatic cytochrome P450 3A4 metabolic activity to the phenomenon of clopidogrel resistance. Circulation. 2004; 109:166-71.

114. Gurbel PA,Tantry US. Clopidogrel resistance? Thromb Res. 2007; 120:311-21.

115. Lepantalo A, Virtanen KS, Heikkila J, Wartiovaara U, Lassila R. Limited early antiplatelet effect of $300 \mathrm{mg}$ clopidogrel in patients with aspirin therapy undergoing percutaneous coronary interventions. Eur Heart J. 2004; $25: 476-83$

116. Angiolillo DJ, Fernandez-Ortiz A, Bernardo E, Ramirez C, Barrera-Ramirez C, Sabate M, et al. Identification of low responders to a 300-mg clopidogrel loading dose in patients undergoing coronary stenting. Thromb Res. 2005; 115:101-8.

117. Brandt JT, Close SL, Iturria SJ, Payne CD, Farid NA, Ernest CS, 2nd, et al. Common polymorphisms of CYP2C19 and CYP2C9 affect the pharmacokinetic and pharmacodynamic response to clopidogrel but not prasugrel. J Thromb Haemost. 2007; 5:2429-36.

118. Hulot JS, Bura A, Villard E, Azizi M, Remones V, Goyenvalle C, et al. Cytochrome P450 2C19 loss-offunction polymorphism is a major determinant of clopidogrel responsiveness in healthy subjects. Blood. 2006; 108:2244-7.

119. Abergel E,Nikolsky E. Ticagrelor: an investigational oral antiplatelet treatment for reduction of major adverse cardiac events in patients with acute coronary syndrome. Vasc Health Risk Manag. 2010; 6:963-77.

120. Brandt JT, Payne CD, Wiviott SD, Weerakkody G, Farid NA, Small DS, et al. A comparison of prasugrel and clopidogrel loading doses on platelet function: magnitude of platelet inhibition is related to active metabolite formation. Am Heart J. 2007; 153:66 e9-16.

121. Farid NA, Smith RL, Gillespie TA, Rash TJ, Blair PE, Kurihara A, et al. The disposition of prasugrel, a novel thienopyridine, in humans. Drug Metab Dispos. 2007; 35:1096-104.

122. Rehmel JL, Eckstein JA, Farid NA, Heim JB, Kasper SC, Kurihara A, et al. Interactions of two major metabolites of prasugrel, a thienopyridine antiplatelet agent, with the cytochromes P450. Drug Metab Dispos. 2006; 34:600-7.

123. Sugidachi A, Asai F, Ogawa T, Inoue T, Koike H. The in vivo pharmacological profile of CS-747, a novel antiplatelet agent with platelet ADP receptor antagonist properties. Br J Pharmacol. 2000; 129:1439-46.

124. Jernberg T, Payne CD, Winters KJ, Darstein C, Brandt JT, Jakubowski JA, et al. Prasugrel achieves greater inhibition of platelet aggregation and a lower rate of non-responders compared with clopidogrel in aspirintreated patients with stable coronary artery disease. Eur Heart J. 2006; 27:1166-73. 
125. Iyu D, Glenn JR, White AE, Fox SC, Dovlatova N, Heptinstall S. P2Y and EP3 antagonists promote the inhibitory effects of natural modulators of platelet aggregation that act via cAMP. Platelets. 2011; 22:504-15.

126. Wiviott SD, Trenk D, Frelinger AL, O'donoghue M, Neumann FJ, Michelson AD, et al. Prasugrel compared with high loading- and maintenance-dose clopidogrel in patients with planned percutaneous coronary intervention: the Prasugrel in Comparison to Clopidogrel for Inhibition of Platelet Activation and AggregationThrombolysis in Myocardial Infarction 44 trial. Circulation. 2007; 116:2923-32.

127. Wiviott SD, Braunwald E, Mccabe CH, Montalescot G, Ruzyllo W, Gottlieb S, et al. Prasugrel versus clopidogrel in patients with acute coronary syndromes. N Engl J Med. 2007; 357:2001-15.

128. Teng R,Butler K. Pharmacokinetics, pharmacodynamics, tolerability and safety of single ascending doses of ticagrelor, a reversibly binding oral P2Y(12) receptor antagonist, in healthy subjects. Eur J Clin Pharmacol. 2010; 66:487-96.

129. Springthorpe B, Bailey A, Barton P, Birkinshaw TN, Bonnert RV, Brown RC, et al. From ATP to AZD6140: the discovery of an orally active reversible P2Y12 receptor antagonist for the prevention of thrombosis. Bioorg Med Chem Lett. 2007; 17:6013-8.

130. Van Giezen JJ, Nilsson L, Berntsson P, Wissing BM, Giordanetto F, Tomlinson W, et al. Ticagrelor binds to human P2Y(12) independently from ADP but antagonizes ADP-induced receptor signaling and platelet aggregation. J Thromb Haemost. 2009; 7:1556-65.

131. Iyu D, Glenn JR, White AE, Fox SC, Van Giezen H, Nylander S, et al. Mode of action of P2Y(12) antagonists as inhibitors of platelet function. Thromb Haemost. 2011; 105:96-106.

132. Husted S, Emanuelsson H, Heptinstall S, Sandset PM, Wickens M, Peters G. Pharmacodynamics, pharmacokinetics, and safety of the oral reversible P2Y12 antagonist AZD6140 with aspirin in patients with atherosclerosis: a double-blind comparison to clopidogrel with aspirin. Eur Heart J. 2006; 27:1038-47.

133. Storey RF, Husted S, Harrington RA, Heptinstall S, Wilcox RG, Peters G, et al. Inhibition of platelet aggregation by AZD6140, a reversible oral P2Y12 receptor antagonist, compared with clopidogrel in patients with acute coronary syndromes. J Am Coll Cardiol. 2007; 50:1852-6.

134. Cannon CP, Husted S, Harrington RA, Scirica BM, Emanuelsson H, Peters G, et al. Safety, tolerability, and initial efficacy of AZD6140, the first reversible oral adenosine diphosphate receptor antagonist, compared with clopidogrel, in patients with non-ST-segment elevation acute coronary syndrome: primary results of the DISPERSE-2 trial. J Am Coll Cardiol. 2007; 50:1844-51.

135. Wallentin L, Becker RC, Budaj A, Cannon CP, Emanuelsson H, Held C, et al. Ticagrelor versus clopidogrel in patients with acute coronary syndromes. N Engl J Med. 2009; 361:1045-57.

136. Mahaffey KW, Wojdyla DM, Carroll K, Becker RC, Storey RF, Angiolillo DJ, et al. Ticagrelor compared with clopidogrel by geographic region in the Platelet Inhibition and Patient Outcomes (PLATO) trial. Circulation. 2011; 124:544-54.

137. Gurbel PA, Bliden KP, Butler K, Tantry US, Gesheff T, Wei C, et al. Randomized double-blind assessment of the ONSET and OFFSET of the antiplatelet effects of ticagrelor versus clopidogrel in patients with stable coronary artery disease: the ONSET/OFFSET study. Circulation. 2009; 120:2577-85.

138. James SK, Roe MT, Cannon CP, Cornel JH, Horrow J, Husted S, et al. Ticagrelor versus clopidogrel in patients with acute coronary syndromes intended for non-invasive management: substudy from prospective randomised PLATelet inhibition and patient Outcomes (PLATO) trial. BMJ. 2011; 342:d3527. 
139. Tantry US, Bliden KP, Wei C, Storey RF, Armstrong M, Butler K, et al. First analysis of the relation between CYP2C19 genotype and pharmacodynamics in patients treated with ticagrelor versus clopidogrel: the ONSET/OFFSET and RESPOND genotype studies. Circ Cardiovasc Genet. 2010; 3:556-66.

140. Wallentin L, James S, Storey RF, Armstrong M, Barratt BJ, Horrow J, et al. Effect of CYP2C19 and ABCB1 single nucleotide polymorphisms on outcomes of treatment with ticagrelor versus clopidogrel for acute coronary syndromes: a genetic substudy of the PLATO trial. Lancet. 2010; 376:1320-8.

141. Gurbel PA, Bliden KP, Butler K, Antonino MJ, Wei C, Teng R, et al. Response to ticagrelor in clopidogrel nonresponders and responders and effect of switching therapies: the RESPOND study. Circulation. 2010; 121:1188-99.

142. Serebruany VL, Stebbing J, Atar D. Dyspnoea after antiplatelet agents: the AZD6140 controversy. Int J Clin Pract. 2007; 61:529-33.

143. Storey RF, Bliden KP, Patil SB, Karunakaran A, Ecob R, Butler K, et al. Incidence of dyspnea and assessment of cardiac and pulmonary function in patients with stable coronary artery disease receiving ticagrelor, clopidogrel, or placebo in the ONSET/OFFSET study. J Am Coll Cardiol. 2010; 56:185-93.

144. Greenbaum AB, Grines CL, Bittl JA, Becker RC, Kereiakes DJ, Gilchrist IC, et al. Initial experience with an intravenous P2Y12 platelet receptor antagonist in patients undergoing percutaneous coronary intervention: results from a 2-part, phase II, multicenter, randomized, placebo- and active-controlled trial. Am Heart J. 2006; 151:689 e1- e10.

145. Storey RF. The P2Y12 receptor as a therapeutic target in cardiovascular disease. Platelets. 2001; 12:197209.

146. Srinivasan S, Mir F, Huang JS, Khasawneh FT, Lam SC, Le Breton GC. The P2Y12 antagonists, 2 methylthioadenosine 5'-monophosphate triethylammonium salt and cangrelor (ARC69931MX), can inhibit human platelet aggregation through a Gi-independent increase in cAMP levels. J Biol Chem. 2009; 284:1610817.

147. Jacobsson F, Swahn E, Wallentin L, Ellborg M. Safety profile and tolerability of intravenous ARC69931MX, a new antiplatelet drug, in unstable angina pectoris and non-Q-wave myocardial infarction. Clin Ther. 2002; 24:752-65.

148. Greenbaum AB, Ohman EM, Gibson CM, Borzak S, Stebbins AL, Lu M, et al. Preliminary experience with intravenous P2Y12 platelet receptor inhibition as an adjunct to reduced-dose alteplase during acute myocardial infarction: results of the Safety, Tolerability and Effect on Patency in Acute Myocardial Infarction (STEP-AMI) angiographic trial. Am Heart J. 2007; 154:702-9.

149. Steinhubl SR, Oh JJ, Oestreich JH, Ferraris S, Charnigo R, Akers WS. Transitioning patients from cangrelor to clopidogrel: pharmacodynamic evidence of a competitive effect. Thromb Res. 2008; 121:527-34.

150. Dovlatova NL, Jakubowski JA, Sugidachi A, Heptinstall S. The reversible P2Y antagonist cangrelor influences the ability of the active metabolites of clopidogrel and prasugrel to produce irreversible inhibition of platelet function. J Thromb Haemost. 2008; 6:1153-9.

151. Bhatt DL, Lincoff AM, Gibson CM, Stone GW, Mcnulty S, Montalescot G, et al. Intravenous platelet blockade with cangrelor during PCI. N Engl J Med. 2009; 361:2330-41.

152. Harrington RA, Stone GW, Mcnulty S, White HD, Lincoff AM, Gibson CM, et al. Platelet inhibition with cangrelor in patients undergoing PCI. N Engl J Med. 2009; 361:2318-29. 
153. Angiolillo DJ, Firstenberg MS, Price MJ, Tummala PE, Hutyra M, Welsby IJ, et al. Bridging antiplatelet therapy with cangrelor in patients undergoing cardiac surgery: a randomized controlled trial. JAMA. 2012; 307:265-74.

154. Lieu H, Conley PB, Andre P, Leese PT, Romanko K, Phillips DR, et al. Initial intravenous experience with PRT060128 (PRT128), an orally-available, direct-acting, and reversible P2Y12 inhibitor. . J Thromb Haemost 2007; 5:P-T-292.

155. Ueno M, Rao SV, Angiolillo DJ. Elinogrel: pharmacological principles, preclinical and early phase clinical testing. Future Cardiol. 2010; 6:445-53.

156. Berger JS, Roe MT, Gibson CM, Kilaru R, Green CL, Melton L, et al. Safety and feasibility of adjunctive antiplatelet therapy with intravenous elinogrel, a direct-acting and reversible P2Y12 ADP-receptor antagonist, before primary percutaneous intervention in patients with ST-elevation myocardial infarction: the Early Rapid ReversAl of platelet thromboSis with intravenous Elinogrel before PCI to optimize reperfusion in acute Myocardial Infarction (ERASE MI) pilot trial. Am Heart J. 2009; 158:998-1004 e1.

157. Leonardi S, Rao SV, Harrington RA, Bhatt DL, Gibson CM, Roe MT, et al. Rationale and design of the randomized, double-blind trial testing INtraveNous and Oral administration of elinogrel, a selective and reversible P2Y(12)-receptor inhibitor, versus clopidogrel to eVAluate Tolerability and Efficacy in nonurgent Percutaneous Coronary Interventions patients (INNOVATE-PCI). Am Heart J. 2010; 160:65-72.

158. Gurbel PA, Bliden KP, Antonino MJ, Stephens G, Gretler DD, Jurek MM, et al. The effect of elinogrel on high platelet reactivity during dual antiplatelet therapy and the relation to CYP2C19*2 genotype: first experience in patients. J Thromb Haemost. 2010; 8:43-53.

159. Andre P, Deguzman F, Haberstock-Debic H, Mills S, Pak Y, Inagaki M, et al. Thienopyridines, but not elinogrel, result in off-target effects at the vessel wall that contribute to bleeding. J Pharmacol Exp Ther. 2011; 338:22-30.

160. Haberstock-Debic H, Andre P, Mills S, Phillips DR, Conley PB. A clopidogrel-insensitive inducible pool of P2Y12 receptors contributes to thrombus formation: inhibition by elinogrel, a direct-acting, reversible P2Y12 antagonist. J Pharmacol Exp Ther. 2011; 339:54-61. 
Fig 1 Biochemistry of human $\mathrm{P}_{2} \mathrm{Y}_{12}$ receptor. The human $\mathrm{P}_{2} \mathrm{Y}_{12}$ receptor structure contains 7 hydrophobic transmembrane (TM) regions connected by 3 extracellular loops (EL) and 3 intracellular loops. The human P2 $Y_{12}$ receptor contains 342 amino acid residues with 10 cysteine residues. Four extracellular cysteines are at position 17, 97, 175, and 270 which are likely to form 2 disulfide bridges between N-terminal domain and EL3, and between EL1 and EL2. There are five cysteine residues at position 194, 208, 248, 292, and 302 within the transmembrane domains, and one intracellular cysteine residue at position 315.

Fig 2 Overview of purinergic $\mathrm{P}_{2} \mathrm{Y}_{12}$ receptor signaling in platelets. While the $\mathrm{P} 2 \mathrm{Y}_{1}$ receptor initiates platelet activation in response to $\mathrm{ADP}, \mathrm{P} 2 \mathrm{Y}_{12}$ receptor completes and amplifies platelet activation and aggregation. The P2 $Y_{12}$ receptor couples to $\mathrm{G}_{\mathrm{i} 2} \mathrm{G}$ protein subunit pathway. Agonists, e.g. ADP, stimulate the heterotrimeric $\mathrm{G}$ protein resulting in dissociation of $\mathrm{G} \alpha$ and $\mathrm{G} \beta \gamma$ subunits. The $\mathrm{G \alpha}_{\mathrm{i} 2}$ inhibits production of adenyl cyclase hence reduces cytosolic cyclic adenosine monophosphate (cAMP) concentrations, cAMP-dependent protein kinase (PKA) and phosphorylated vasodilator-stimulated phosphoprotein (VASP). On the other hand, G $\beta \gamma$ subunit stimulates phosphatidyl inositol-3 kinase (PI-3K), Raplb and Akt activities. In addition, the $\beta \gamma$ dimers can activate the G-protein-gated inwardly rectifying potassium channels (GIRKs) that in conjunction with $\mathrm{P}_{2} \mathrm{Y}_{1}$ signaling pathways mediating activation of Src, ERK, cytosolic phospholipase $\mathrm{A}_{2}\left(\mathrm{cPLA}_{2}\right)$ and thromboxane $\mathrm{A}_{2}$ generation. 